\title{
Screening for cervical cancer: a systematic review and meta-analysis
}

\author{
Leslea Peirson ${ }^{*}$, Donna Fitzpatrick-Lewis, Donna Ciliska and Rachel Warren
}

\begin{abstract}
Background: The systematic review on which this paper is based provided evidence for the Canadian Task Force on Preventive Health Care to update their guideline regarding screening for cervical cancer. In this article we highlight three questions covered in the full review that pertain to the effectiveness of screening for reducing cervical cancer mortality and incidence as well as optimal timing and frequency of screening.

Methods: We searched MEDLINE, Embase and Cochrane Central from 1995 to 2012 for relevant randomized controlled trials and observational studies with comparison groups. Eligible studies included women aged 15 to 70 years who were screened using conventional cytology, liquid-based cytology or human papillomavirus DNA tests. Relevance screening, data extraction, risk of bias analyses and quality assessments were performed in duplicate. We conducted a meta-analysis using a random-effects model on the one body of evidence that could be pooled.
\end{abstract}

Results: From the 15,145 screened citations, 27 papers (24 studies) were included; five older studies located in a United States Preventive Services Task Force review were also included. A randomized controlled trial in India showed even a single lifetime screening test significantly decreased the risk of mortality from and incidence of advanced cervical cancer compared to no screening (mortality: risk ratio 0.65, 95\% confidence interval 0.47, 0.90; incidence: relative risk $0.56,95 \%$ confidence interval $0.42,0.75$ ). Cytology screening was shown to be beneficial in a cohort study that found testing significantly reduced the risk of being diagnosed with invasive cervical cancer compared to no screening (risk ratio $0.38 ; 95 \%$ confidence interval $0.23,0.63$ ). Pooled evidence from a dozen case-control studies also indicated a significant protective effect of cytology screening (odds ratio $0.35 ; 95 \%$ confidence interval $0.30,0.41$ ). This review found no conclusive evidence for establishing optimal ages to start and stop cervical screening, or to determine how often to screen; however the available data suggests substantial protective effects for screening women 30 years and older and for intervals of up to five years.

Conclusions: The available evidence supports the conclusion that cervical screening does offer protective benefits and is associated with a reduction in the incidence of invasive cervical cancer and cervical cancer mortality.

Keywords: Cervical cancer, Screening, Systematic review

\section{Background}

Cervical cancer is a treatable disease and tertiary interventions have contributed to reductions in mortality rates [1]. However, when downstream activities are combined with preventive efforts, there is greater impact in terms of lives saved. There is widespread acceptance that regular screening is the single most important public health strategy to reduce cervical cancer incidence and subsequent mortality. Screening tests such as conventional

\footnotetext{
* Correspondence: peirson@mcmaster.ca

McMaster Evidence Review and Synthesis Centre (MERSC), 1280 Main Street West, DTC-322, Hamilton, ON L8S 4K1, Canada
}

cytology (commonly referred to as the Pap smear) are used to identify pre-cancers, which can be treated to prevent the occurrence of invasive cancer or allow the disease to be identified at an earlier stage, permitting more effective treatment. The systematic review on which this paper is based provided evidence for the Canadian Task Force on Preventive Health Care to update their guideline regarding screening of average-risk women for cervical cancer $[2,3]$.

Much of the recent research has focused on reductions in precursor cervical lesions, which are more common and present earlier outcomes for measurement during

\section{Biomed Central}


trials. However, evidence from a treated versus not-treated cohort study with 30-year follow-up suggests a third of cases with precursor lesions will advance to invasive cancer [4]. Consequently, cervical cancer mortality and incidence of invasive cervical cancer were designated as the critical outcomes for this review. To our knowledge, no published systematic review has addressed the question of screening effectiveness with these outcomes, and until recently there were no randomized controlled trials (RCTs) to inform decision-making. Instead, ecological studies have been used to demonstrate that mortality from cervical cancer decreased as screening became more widespread [5,6]. However, higher level evidence is available. In this article we highlight three questions covered in the full systematic review:

1. What is the effect of cervical cancer screening on incidence of and mortality from invasive cervical cancer?

2. How does varying the screening interval affect incidence of and mortality from invasive cervical cancer?

3. How does varying the age at which screening is started or stopped reduce incidence of and mortality from invasive cervical cancer?

The PICOS (population, intervention, comparator, outcome, study design) framework for these questions was as follows: (P) asymptomatic women aged 15 to 70 years with a history of sexual activity, (I) conventional cervical cytology, liquid-based cervical cytology or human papillomavirus (HPV) DNA screening tests, $(\mathrm{C})$ no screening, $(\mathrm{O})$ cervical cancer mortality and incidence of invasive cervical cancer, and (S) RCTs and observational studies with comparison groups.

\section{Methods}

\section{Search strategy and eligibility criteria}

For the questions addressed in this paper, MEDLINE, Embase and Cochrane Central Register of Controlled Trials were searched from 1995 to April 2012 for studies conducted in any country and published in English or French. As above, results were limited to systematic reviews, RCTs and observational studies with comparison groups, involving asymptomatic women aged 15 to 70 years with a history of sexual activity, who were screened using conventional cytology, liquid-based cytology or HPV DNA tests. These specific tests were purposefully selected as they are the most relevant screening modalities for the Canadian context, for which subsequent screening guidelines would be developed. The outcomes of interest were cervical cancer mortality and incidence of invasive cervical cancer. In addition, we examined two United States Preventive Services Task Force (USPSTF) reviews on cervical screening for any relevant studies not captured by our search strategy $[7,8]$. Reference lists of on-topic systematic reviews were also searched to ensure all primary studies meeting our inclusion criteria were considered. A focused search of PubMed, specifically for RCTs on cervical screening, was undertaken on November 5 2012, several weeks in advance of the release of the Canadian Task Force on Preventive Health Care guideline.

\section{Study selection and data extraction}

Pairs of reviewers screened all identified citations. Any citation deemed potentially relevant was retrieved for full text review. Two reviewers independently assessed each full text article for eligibility. Disagreements were resolved through discussion. For each included study, two reviewers independently extracted relevant outcome data and study details. Conflicts were resolved through discussion.

\section{Quality assessment}

Risk of bias assessments were completed in duplicate. Quality of the evidence was determined using the GRADE system (Grading of Recommendations Assessment, Development and Evaluation). This considers five criteria (design, consistency, directness, precision, reporting bias) to rate of a body of evidence as high, moderate, low or very low, indicating the assessment of the likelihood that further research will impact the estimate of effect [9]. After two reviewers independently assessed the evidence on the criteria, agreement was reached on the ratings and the overall quality of the summary statistics.

\section{Statistical analysis}

For the one included RCT we combined the cytology and HPV testing arms into a single screening group that was compared to the control group on the outcomes of cervical cancer mortality, incidence of all cervical cancer, and incidence of stage II or higher cervical cancer. Event rates were entered into Cochrane's Review Manager 5 (RevMan) software [10] and a fixed-effects model was used to compute a risk ratio for each outcome.

A single cohort study provided data for the incidence outcome. To be consistent in the presentation of findings, the reported estimate of effect was inverted to provide the risk for the screened group with the unscreened group as the referent.

We also conducted a meta-analysis using data from case-control studies that examined the odds of exposure to cytology screening among women diagnosed with invasive cervical cancer and women with no history of the disease. RevMan [10] was used to perform the metaanalysis using the generic inverse variance method and the random-effects model [11]. We used $\mathrm{Chi}^{2}$ and $\mathrm{I}^{2}$ values to test for heterogeneity [12-14]. Post hoc sensitivity analyses 
(based on contextually and clinically important differences in study designs, populations, interventions, organized versus opportunistic approaches, and length of exposure to screening) were conducted to attempt to explain heterogeneity.

\section{Results}

\section{Study selection and characteristics}

Figure 1 shows the selection of studies. The search strategy located 15,145 citations after duplicates were removed, approximately $4 \%(n=531)$ of which passed relevance screening and went on to full text assessment. Of these, 27 papers (24 unique studies) met all criteria and were included in the full review. In addition, five studies in the 1996 USPSTF report that pre-dated our search parameters were added to the evidence [15-19]. The 2011 USPSTF report contained no studies that met our inclusion criteria that were not already part of this review and no additional primary studies were located in the reference lists of other systematic reviews. The supplemental search of PubMed in November 2012 located 10 new citations, however none of these were RCTs that met the inclusion criteria for this review.

For the three questions covered in this paper, we identified one RCT [20], two cohort studies [21,22] and 18 case-control studies (one study had four publications) [15-19,23-38]. Fourteen of these studies were used to examine the question of screening effectiveness, 14 studies (16 papers) provided data on screening intervals, and four studies (six papers) provided data that considered ages to initiate and discontinue screening. The RCT considered both cytology and HPV screening tests; all observational studies considered only cytology. Additional characteristics of these 21 studies are summarized in Table 1.

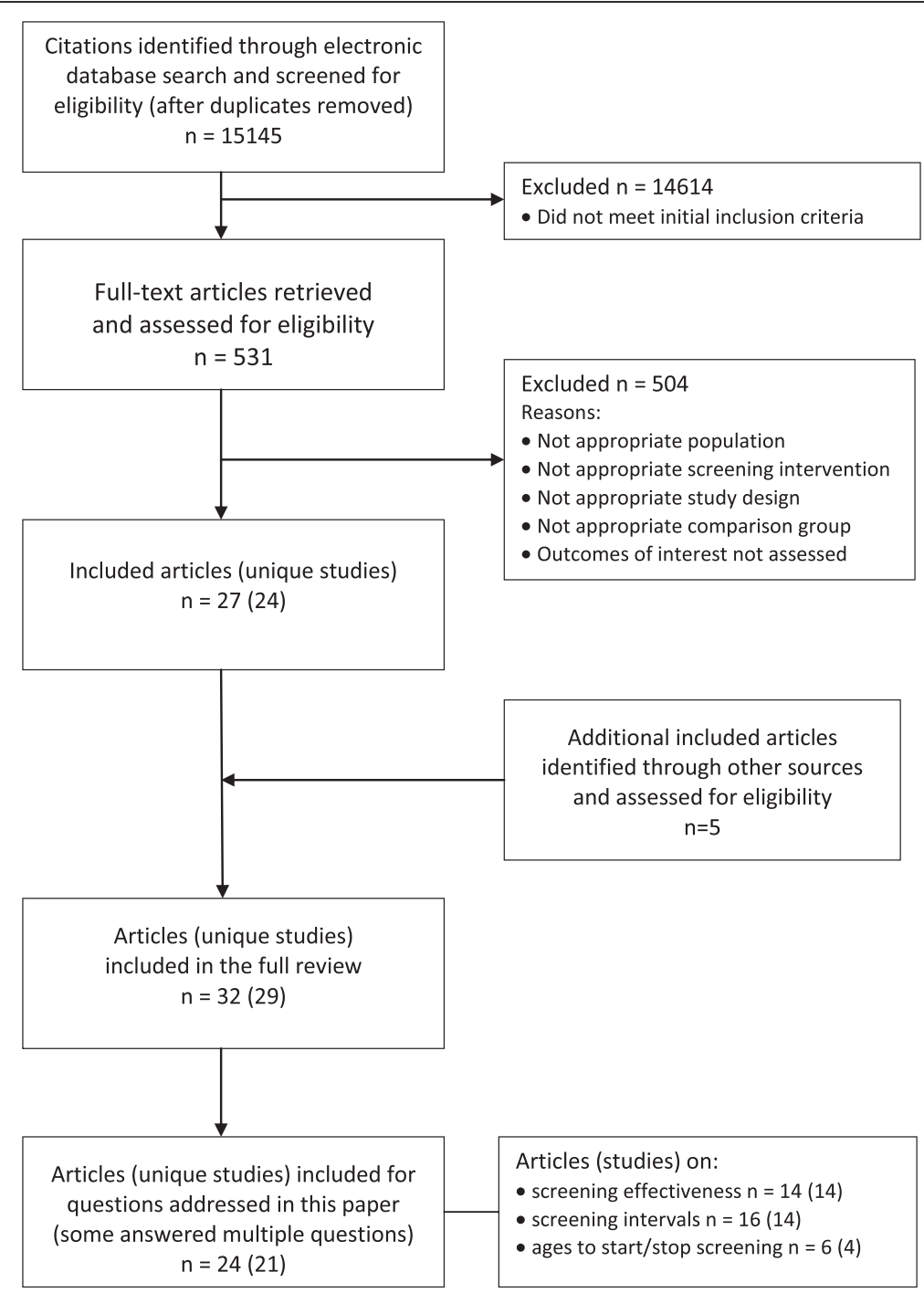

Figure 1 Flow diagram for selection of studies included in the systematic review. 
Table 1 Characteristics of the included studies

\section{Randomized (cluster) controlled tria}

\begin{tabular}{|c|c|c|c|c|c|c|c|c|c|}
\hline \multirow[t]{2}{*}{ Study } & \multirow[t]{2}{*}{ Location } & \multicolumn{2}{|c|}{$\begin{array}{l}\text { Number of } \\
\text { participants }\end{array}$} & \multirow[t]{2}{*}{$\begin{array}{l}\text { Ages } \\
\text { (years) }\end{array}$} & \multirow[t]{2}{*}{ Screening exposure } & \multirow[t]{2}{*}{ Disease definition } & \multirow[t]{2}{*}{ Participant eligibility } & \multirow[t]{2}{*}{$\begin{array}{l}\text { Post screening } \\
\text { treatment }\end{array}$} & \multirow[t]{2}{*}{ Follow-up } \\
\hline & & Intervention & Control & & & & & & \\
\hline $\begin{array}{l}\text { Sankaranarayanan } \\
\text { et al. [20] }\end{array}$ & India & $\begin{array}{l}\text { HPV: } 34,126 \\
\text { Cytology: } 32,058\end{array}$ & 31,488 & 30 to 59 & $\begin{array}{l}\text { Only } 8(<0.007 \%) \text { of the eligible } \\
\text { women had ever been screened }\end{array}$ & $\begin{array}{l}\text { Invasive cervical } \\
\text { cancer; FIGO } \\
\text { stages I+ }\end{array}$ & No history of cervical cancer & $\begin{array}{l}\text { Cryotherapy, LEEP, } \\
\text { conization offered } \\
\text { for CIN; invasive } \\
\text { cancer referred for } \\
\text { treatment (surgery, } \\
\text { radiotherapy) }\end{array}$ & $\begin{array}{l}8 \text { years } 2000 \\
\text { to } 2007\end{array}$ \\
\hline \multicolumn{10}{|l|}{ Cohort studies } \\
\hline Study & Location & \multicolumn{2}{|c|}{$\begin{array}{l}\text { Number of } \\
\text { participants }\end{array}$} & $\begin{array}{l}\text { Ages } \\
\text { (years) }\end{array}$ & Screening exposure & Disease definition & Participant eligibility & $\begin{array}{l}\text { Post screening } \\
\text { treatment }\end{array}$ & Follow-up \\
\hline \multirow[t]{2}{*}{ Herbert et al. [21] } & \multirow[t]{2}{*}{ UK } & \multirow{2}{*}{\multicolumn{2}{|c|}{$\begin{array}{l}116,022 \text { (four groups } \\
\text { based on screening } \\
\text { history) }\end{array}$}} & \multirow[t]{2}{*}{25 to 69} & $\begin{array}{l}\text { Interval since last smear: }<3.5 \mathrm{y} \text {, } \\
3.5 \text { to } 5.5 \mathrm{y}_{1}>5.5 \mathrm{y} \text {, no record }\end{array}$ & \multirow{2}{*}{$\begin{array}{l}\text { Invasive cervical } \\
\text { cancer; FIGO } \\
\text {-stages I+ }\end{array}$} & \multirow[t]{2}{*}{ No hysterectomy } & \multirow[t]{2}{*}{ NR } & \multirow[t]{2}{*}{$\begin{array}{l}3 \text { years } 1991 \\
\text { to } 1993\end{array}$} \\
\hline & & & & & $\begin{array}{l}\text { Excluded: smears to investigate } \\
\text { symptoms, referral smears in } \\
\text { screen-detected cases }\end{array}$ & & & & \\
\hline \multirow[t]{3}{*}{ Rebolj et al. [22] } & \multirow[t]{3}{*}{ Netherlands } & \multirow{3}{*}{\multicolumn{2}{|c|}{$\begin{array}{l}\text { Cohort 1: } 445,382 \\
\text { Cohort 2: } 218,847\end{array}$}} & \multirow{3}{*}{$\begin{array}{l}\text { C1: } 30 \\
\text { to } 44 \\
\text { C2: } 45 \\
\text { to } 54\end{array}$} & $\begin{array}{l}\text { Mean interval between three } \\
\text { consecutive negative results }\end{array}$ & \multirow{3}{*}{$\begin{array}{l}\text { Invasive cervical } \\
\text { cancer; FIGO } \\
\text {-stages NR }\end{array}$} & \multirow{3}{*}{$\begin{array}{l}\text { Three consecutive negative } \\
\text { smears in age interval; no } \\
\text { history of CIN or cytological } \\
\text { abnormalities }\end{array}$} & \multirow[t]{3}{*}{ NR } & \multirow[t]{3}{*}{$\begin{array}{l}10 \text { years } 1994 \\
\text { to } 2002\end{array}$} \\
\hline & & & & & C1: $39 \mathrm{~m}$ & & & & \\
\hline & & & & & $\mathrm{C} 2: 40 \mathrm{~m}$ & & & & \\
\hline \multicolumn{10}{|c|}{ Case control studies } \\
\hline \multirow[t]{2}{*}{ Study } & \multirow[t]{2}{*}{ Location } & \multicolumn{2}{|c|}{$\begin{array}{l}\text { Number of } \\
\text { participants }\end{array}$} & \multirow[t]{2}{*}{$\begin{array}{l}\text { Ages } \\
\text { (years) }\end{array}$} & \multirow[t]{2}{*}{ Screening exposure/history } & \multirow[t]{2}{*}{$\begin{array}{l}\text { Case/disease } \\
\text { definition }\end{array}$} & \multirow[t]{2}{*}{ Control eligibility } & $\begin{array}{l}\text { Post screening } \\
\text { treatment }\end{array}$ & $\begin{array}{l}\text { Case } \\
\text { diagnosis }\end{array}$ \\
\hline & & Cases & Controls & & & & & & \\
\hline Andrae et al. [24] & Sweden & 1,230 & 6,124 & 20 to 99 & $\begin{array}{l}\text { Interval since last smear: } 6 \\
\text { to } 42 \mathrm{~m} \text { (ages }<53 \text { ), } 6 \text { to } 66 \mathrm{~m} \\
\text { (ages } 54 \text { to } 65), 6 \text { to } 78 \mathrm{~m} \\
\text { (ages } \geq 66 \text { ), not screened } \\
\text { during interval }\end{array}$ & $\begin{array}{l}\text { Invasive cervical } \\
\text { cancer; FIGO } \\
\text { stages } 1+\end{array}$ & $\begin{array}{l}\text { No history of cervical cancer; } \\
\text { alive on case diagnosis date }\end{array}$ & NR & 1999 to 2001 \\
\hline & & & & & $\begin{array}{l}\text { Excluded: smears }<6 \mathrm{~m} \text { prior to } \\
\text { case diagnosis }\end{array}$ & & & & \\
\hline $\begin{array}{l}\text { Aristizabal } \\
\text { et al. [15] }\end{array}$ & Colombia & 277 & 554 & 16 to 60 & $\begin{array}{l}\text { Interval since last smear: } 12 \text { to } \\
72 \mathrm{~m} \text { prior to case diagnosis }\end{array}$ & $\begin{array}{l}\text { Invasive cervical } \\
\text { cancer; excluded }\end{array}$ & $\begin{array}{l}\text { Out-patient services from } \\
\text { same clinic where case }\end{array}$ & NR & 1977 to 1981 \\
\hline & & & & & $\begin{array}{l}\text { Excluded: smears }<12 \mathrm{~m} \text { prior to } \\
\text { diagnosis/index date }\end{array}$ & in situ & $\begin{array}{l}\text { diagnosed or reside in } \\
\text { same area as case }\end{array}$ & & \\
\hline Berrino et al. [16] & Italy & 121 & 350 & $N R$ & $\begin{array}{l}\text { Interval since last negative smear: } \\
0 \text { to } 11 \mathrm{~m}, 12 \text { to } 23 \mathrm{~m}, 24 \text { to } \\
35 \mathrm{~m}, 36 \text { to } 47 \mathrm{~m}, 48+\mathrm{m} \text {, no } \\
\text { prior negative smear }\end{array}$ & $\begin{array}{l}\text { Invasive cervical } \\
\text { cancer; FIGO } \\
\text { stages I+ }\end{array}$ & $\begin{array}{l}\text { Married women hospitalized } \\
\text { for and diagnosed with } \\
\text { non-gynecological diseases; } \\
\text { no history of breast cancer } \\
\text { or hysterectomy }\end{array}$ & $\begin{array}{l}\text { Two controls had } \\
\text { been treated for } \\
\text { carcinoma in situ } \\
\text { after a positive } \\
\text { smear result }\end{array}$ & 1978 \\
\hline
\end{tabular}


Table 1 Characteristics of the included studies (Continued)

\begin{tabular}{|c|c|c|c|c|c|c|c|c|c|}
\hline & & & & & $\begin{array}{l}\text { Included: smears prior to } \\
\text { symptoms (cases), smears } \\
\text { prior to study mid-point } \\
\text { (controls) }\end{array}$ & & & & \\
\hline \multirow[t]{2}{*}{$\begin{array}{l}\text { Clarke and } \\
\text { Anderson [17] }\end{array}$} & \multirow[t]{2}{*}{ Canada } & \multirow[t]{2}{*}{212} & \multirow[t]{2}{*}{1,060} & \multirow[t]{2}{*}{ Mean 52} & $\begin{array}{l}\text { Interval since last smear: } \\
<5 \text { y prior to case diagnosis }\end{array}$ & \multirow{2}{*}{$\begin{array}{l}\text { Invasive cervical } \\
\text { cancer; most }<6 \mathrm{~m} \\
\text {-post diagnosis }\end{array}$} & \multirow[t]{2}{*}{ No exclusion for hysterectomy } & \multirow[t]{2}{*}{ NR } & \multirow[t]{2}{*}{1973 to 1976} \\
\hline & & & & & $\begin{array}{l}\text { Included: non-symptomatic, } \\
\text { routine examination smears }\end{array}$ & & & & \\
\hline \multirow[t]{2}{*}{ Decker et al. [25] } & \multirow[t]{2}{*}{ Canada } & \multirow[t]{2}{*}{666} & \multirow[t]{2}{*}{3,343} & \multirow[t]{2}{*}{$\begin{array}{l}\geq 18 \\
\text { Mean } 50\end{array}$} & $\begin{array}{l}\text { Interval since last smear: }<5 \text { y } \\
\text { prior to case diagnosis }\end{array}$ & \multirow{2}{*}{$\begin{array}{l}\text { Invasive cervical } \\
\text { cancer; FIGO } \\
\text {-stages I+ }\end{array}$} & \multirow{2}{*}{$\begin{array}{l}\text { No history of cervical cancer } \\
\text { or malignant neoplasms } \\
\text { (excluding non-melanoma } \\
\text { skin cancer); no hysterectomy }\end{array}$} & \multirow[t]{2}{*}{ NR } & \multirow[t]{2}{*}{1989 to 2001} \\
\hline & & & & & $\begin{array}{l}\text { Excluded: smears }<6 \mathrm{~m} \text { prior } \\
\text { to case diagnosis }\end{array}$ & & & & \\
\hline \multirow[t]{2}{*}{$\begin{array}{l}\text { Hernández-Avila } \\
\text { et al. [26] }\end{array}$} & \multirow[t]{2}{*}{ Mexico } & \multirow[t]{2}{*}{397} & \multirow[t]{2}{*}{1,005} & \multirow[t]{2}{*}{$\begin{array}{l}25 \text { to } 80 \\
\text { Mean } 48\end{array}$} & $\begin{array}{l}\text { Exposure: any lifetime } \\
\text { smear(s), no history }\end{array}$ & \multirow[t]{2}{*}{$\begin{array}{l}\text { Invasive cervical } \\
\text { cancer }\end{array}$} & \multirow[t]{2}{*}{$\begin{array}{l}\text { Eligibility limited only by age } \\
\text { and area of residence }\end{array}$} & \multirow[t]{2}{*}{ NR } & \multirow[t]{2}{*}{1990 to 1992} \\
\hline & & & & & $\begin{array}{l}\text { Excluded: smears }<12 \mathrm{~m} \\
\text { prior to case diagnosis or } \\
\text { control interview }\end{array}$ & & & & \\
\hline \multirow[t]{2}{*}{ Herrero et al. [18] } & \multirow[t]{2}{*}{ Latin America } & \multirow[t]{2}{*}{759} & \multirow[t]{2}{*}{1,430} & \multirow[t]{2}{*}{$<70$} & $\begin{array}{l}\text { Interval since last smear: } 12 \\
\text { to } 23 \mathrm{~m}, 24 \text { to } 47 \mathrm{~m} \text {, never } \\
\text { screened }\end{array}$ & \multirow[t]{2}{*}{$\begin{array}{l}\text { Invasive cervical } \\
\text { cancer; FIGO } \\
\text { stages I+ }\end{array}$} & \multirow{2}{*}{$\begin{array}{l}\text { No history of psychiatric } \\
\text { diagnoses, hysterectomy, } \\
\text { cancer, or diseases related to } \\
\text { exposures of interest; history } \\
\text { of sexual intercourse }\end{array}$} & \multirow[t]{2}{*}{ NR } & \multirow[t]{2}{*}{1986 to 1987} \\
\hline & & & & & $\begin{array}{l}\text { Excluded: smears }<1 \text { y prior } \\
\text { to interview (mean interval } \\
\text { between case diagnosis and: } \\
\text { case interview } 1 \mathrm{~m} \text {; control } \\
\text { interview } 2.3 \mathrm{~m} \text { ) }\end{array}$ & & & & \\
\hline $\begin{array}{l}\text { Hoffman } \\
\text { et al. [27] }\end{array}$ & South Africa & 524 & 1,540 & $<60$ & $\begin{array}{l}\text { Interval since last smear: }<5 y \text {, } \\
5 \text { to } 9 y, 10 \text { to } 14 y_{1} \geq 15 y \text {, } \\
\text { unknown, never }\end{array}$ & $\begin{array}{l}\text { Invasive cervical } \\
\text { cancer; FIGO stages } \\
\text { IB to IV; diagnosed }\end{array}$ & $\begin{array}{l}\text { Hospital admission not } \\
\text { related to risk of } \\
\text { cervical cancer }\end{array}$ & NR & NR late 1990s \\
\hline & & & & & $\begin{array}{l}\text { Analysis excluding smears in } \\
\text { prior } 12 \mathrm{~m} \text { showed no } \\
\text { difference in findings }\end{array}$ & $\begin{array}{l}\leq 6 \mathrm{~m} \text { prior to } \\
\text { study enrollment }\end{array}$ & & & \\
\hline $\begin{array}{l}\text { Jiménez-Pérez } \\
\text { and Thomas [28] }\end{array}$ & Mexico & 143 & 311 & Mean 49 & $\begin{array}{l}\text { Interval since last smear: } 1 \text { to } \\
12 \mathrm{~m}, 13 \text { to } 60 \mathrm{~m},>60 \mathrm{~m} \text {, } \\
\text { unknown, never }\end{array}$ & $\begin{array}{l}\text { Invasive cervical } \\
\text { cancer; FIGO } \\
\text { stages IB to IV }\end{array}$ & $\begin{array}{l}\text { No hysterectomy; not } \\
\text { attending clinic for cervical } \\
\text { screening, or any gynecologic }\end{array}$ & NR & 1991 to 1994 \\
\hline & & & & & $\begin{array}{l}\text { Excluded: smears } \leq 12 \mathrm{~m} \text { prior } \\
\text { to diagnosis/index date }\end{array}$ & & $\begin{array}{l}\text { or obstetric conditions; } \\
\text { history of sexual intercourse }\end{array}$ & & \\
\hline $\begin{array}{l}\text { Kasinpila } \\
\text { et al. [38] }\end{array}$ & Thailand & 130 & 260 & Mean 48 & $\begin{array}{l}\text { Interval since last smear: }<6 \mathrm{~m} \text {, } \\
6 \text { to } 11 \mathrm{~m}, 12 \text { to } 35 \mathrm{~m}, 36+\mathrm{m}, \\
\text { never }\end{array}$ & $\begin{array}{l}\text { Invasive cervical } \\
\text { cancer; diagnosed } \\
\leq 3 \mathrm{~m} \text { prior to }\end{array}$ & $\begin{array}{l}\text { No evidence of cervical } \\
\text { disease or any other } \\
\text { gynecological disease }\end{array}$ & $\begin{array}{l}\text { Cryotherapy and } \\
\text { LEEP offered for } \\
\text { confirmed }\end{array}$ & 2009 \\
\hline & & & & & $\begin{array}{l}\text { Excluded: smears in } \\
\text { previous } 6 \mathrm{~m}\end{array}$ & interview & & abnormalities & \\
\hline $\begin{array}{l}\text { La Vecchia } \\
\text { et al. [19] }\end{array}$ & Italy & 191 & 191 & 22 to 74 & $\begin{array}{l}\text { Interval since last smear: } \\
<3 \mathrm{y}, 3 \text { to } 5 \mathrm{y},>5 \mathrm{y} \text {, never }\end{array}$ & $\begin{array}{l}\text { Invasive cervical } \\
\text { cancer; FIGO } \\
\text { Stages } 1+\end{array}$ & $\begin{array}{l}\text { Admitted and diagnosed } \\
\text { with acute non-malignant, } \\
\text { non-hormonal, } \\
\text { non-gynecological }\end{array}$ & NR & 1981 to 1983 \\
\hline
\end{tabular}


Table 1 Characteristics of the included studies (Continued)

\begin{tabular}{|c|c|c|c|c|c|c|c|c|c|}
\hline & & & & & $\begin{array}{l}\text { Excluded: smears to } \\
\text { investigate symptoms; cases } \\
\text { with positive smear }<1 \text { y } \\
\text { prior to diagnosis }\end{array}$ & & $\begin{array}{l}\text { problems }<1 \text { y prior } \\
\text { to interview }\end{array}$ & & \\
\hline \multirow[t]{3}{*}{ Makino et al. [29] } & \multirow[t]{3}{*}{ Japan } & \multirow[t]{3}{*}{129} & \multirow[t]{3}{*}{396} & \multirow[t]{3}{*}{35 to 79} & $\begin{array}{l}\text { Interval since last negative } \\
\text { smear to diagnosis/index } \\
\text { date: } 1 \text { y, } 2 y, 3 y, 4 y, \geq 5 y\end{array}$ & \multirow{3}{*}{$\begin{array}{l}\text { Invasive cervical } \\
\text { cancer; diagnosed } \\
<6 \mathrm{~m} \text { after abnormal } \\
\text {-smear result }\end{array}$} & \multirow{3}{*}{$\begin{array}{l}\text { No invasive cervical cancer; } \\
\text { no hysterectomy; no } \\
\text { previous abnormal } \\
\text { cytology results; } \\
\text { participated in mass } \\
\text { screening }\end{array}$} & \multirow[t]{3}{*}{ NR } & \multirow[t]{3}{*}{1984 to 1990} \\
\hline & & & & & $\begin{array}{l}\text { Exposure: any lifetime } \\
\text { smear(s), no history }\end{array}$ & & & & \\
\hline & & & & & $\begin{array}{l}\text { Excluded: smears to } \\
\text { investigate symptoms or } \\
\text { taken at time of diagnosis }\end{array}$ & & & & \\
\hline Miller et al. [31] & USA & 482 & 934 & Mean 49 & $\begin{array}{l}\text { Interval from last negative } \\
\text { smear to diagnosis/index } \\
\text { date: } 1 \text { y }(0 \text { to } 18 \mathrm{~m}), 2 \text { y } \\
(19 \text { to } 30 \mathrm{~m}), 3 \text { y }(31 \text { to } \\
42 \mathrm{~m}), 3 \text { to } 5 \text { y }(42 \text { to } \\
66 \mathrm{~m}), 5 \text { to } 10 \text { y }(67 \\
\text { to } 126 \mathrm{~m}),>10 \text { y }(>126 \mathrm{~m})\end{array}$ & $\begin{array}{l}\text { Invasive squamous } \\
\text { cell cervical cancer }\end{array}$ & $\begin{array}{l}\text { No prior hysterectomy or } \\
\text { radiation to the pelvis }\end{array}$ & NR & 1983 to 1995 \\
\hline \multirow[t]{2}{*}{$\begin{array}{l}\text { Nieminen } \\
\text { et al. [23] }\end{array}$} & \multirow[t]{2}{*}{ Finland } & \multirow[t]{2}{*}{179} & \multirow[t]{2}{*}{1,507} & \multirow[t]{2}{*}{$\begin{array}{l}30 \text { to } 91 \\
\text { Mean } 60\end{array}$} & $\begin{array}{l}\text { Exposure: any lifetime } \\
\text { smear(s), no history }\end{array}$ & \multirow[t]{2}{*}{$\begin{array}{l}\text { Invasive cervical } \\
\text { cancer }\end{array}$} & \multirow{2}{*}{$\begin{array}{l}\text { Eligibility limited only by } \\
\text { catchment (reside in } \\
\text { area served by case } \\
\text { treatment hospital) }\end{array}$} & \multirow{2}{*}{$\begin{array}{l}\text { Organized } \\
\text { screening } \\
\text { program } \\
\text { provides } \\
\text { colposcopy } \\
\text { examinations } \\
\text { and treatment } \\
\text { for mild } \\
\text { abnormalities }\end{array}$} & \multirow[t]{2}{*}{1987 to 1994} \\
\hline & & & & & $\begin{array}{l}\text { Excluded: smears }<1 \text { y prior } \\
\text { to diagnosis/index date }\end{array}$ & & & & \\
\hline Sasieni et al. [32] & UK & 348 & 677 & $\geq 20$ & $\begin{array}{l}\text { Interval since last negative } \\
\text { smear (not immediately } \\
\text { following a test showing } \\
\text { abnormal results): } 0 \text { to } 11 \mathrm{~m} \text {, } \\
12 \text { to } 23 \mathrm{~m}, 24 \text { to } 35 \mathrm{~m}, 36 \\
\text { to } 47 \mathrm{~m}, 48 \text { to } 65 \mathrm{~m},>66 \mathrm{~m} \text {, } \\
\text { no history }\end{array}$ & $\begin{array}{l}\text { Invasive cervical } \\
\text { cancer; FIGO } \\
\text { stages IB+ }\end{array}$ & No hysterectomy & NR & 1992 \\
\hline Sasieni et al. [33] & UK & 1,305 & 2,532 & 20 to 69 & $\begin{array}{l}\text { Interval since last negative } \\
\text { smear (no abnormal smear in } \\
\text { prior } 12 \mathrm{~m}):<3 \mathrm{y}, 3<5 \mathrm{y}, 5+\mathrm{y} \text {, } \\
\text { no history of a negative } \\
\text { smear }\end{array}$ & $\begin{array}{l}\text { Invasive cervical } \\
\text { cancer; FIGO } \\
\text { stages IB+ }\end{array}$ & No hysterectomy & $N R$ & 1990 to 2001 \\
\hline Sasieni et al. [34] & UK & 4,012 & 7,889 & 20 to 69 & $\begin{array}{l}\text { Exposure: screening or no } \\
\text { screening during specific age } \\
\text { bands (for example, } 20 \text { to } 21, \\
22 \text { to } 24,20 \text { to } 24 \text { ) related to } \\
\text { cancers diagnosed in specific } \\
\text { and imminent age bands } \\
\text { (for example, } 25 \text { to 29) }\end{array}$ & $\begin{array}{l}\text { Invasive cervical } \\
\text { cancer; FIGO } \\
\text { stages I+ }\end{array}$ & $\begin{array}{l}\text { No hysterectomy; } \\
\text { registered with a National } \\
\text { Health Services general } \\
\text { practitioner, still alive, } \\
\text { not emigrated }\end{array}$ & NR & 1990 to 2008 \\
\hline
\end{tabular}


Table 1 Characteristics of the included studies (Continued)

\begin{tabular}{|c|c|c|c|c|c|c|c|c|c|}
\hline Sasieni et al. [35] & UK & 3,305 & 6,516 & 20 to 69 & $\begin{array}{l}\text { Maximum interval between } \\
\text { smears: }<3.5 \mathrm{y}, 3.5 \text { to } 5.5 \mathrm{y}, \\
>5.5 \mathrm{y} \text { or no smear history }\end{array}$ & $\begin{array}{l}\text { Invasive cervical } \\
\text { cancer; FIGO } \\
\text { stages I+ }\end{array}$ & No hysterectomy & NR & 1990 to 2008 \\
\hline \multirow[t]{2}{*}{ Talbott et al. [30] } & \multirow[t]{2}{*}{ USA } & \multirow[t]{2}{*}{143} & \multirow[t]{2}{*}{143} & \multirow[t]{2}{*}{ Mean 45} & $\begin{array}{l}\text { Exposure: smear }<3 \text { y prior } \\
\text { to case diagnosis or control } \\
\text { interview }\end{array}$ & \multirow{2}{*}{$\begin{array}{l}\text { Invasive cervical } \\
\text { cancer (localized, } \\
\text { regional or distant); } \\
\text {-excluded in situ }\end{array}$} & \multirow[t]{2}{*}{ No hysterectomy } & \multirow[t]{2}{*}{ NR } & \multirow[t]{2}{*}{1984 to 1985} \\
\hline & & & & & $\begin{array}{l}\text { Diagnostic smears: any } \\
\text { positive result }<12 \mathrm{~m} \text { prior } \\
\text { to diagnosis }\end{array}$ & & & & \\
\hline \multirow[t]{2}{*}{ Yang et al. [36] } & \multirow[t]{2}{*}{ Australia } & \multirow[t]{2}{*}{877} & \multirow[t]{2}{*}{2,614} & \multirow[t]{2}{*}{20 to 69} & $\begin{array}{l}\text { Exposure: } 0,1 \text { or } 2+ \\
\text { smears in last } 4 \mathrm{y}\end{array}$ & \multirow{2}{*}{$\begin{array}{l}\text { Invasive cervical } \\
\text { cancer (localized } \\
\text {-and non-localized) }\end{array}$} & \multirow{2}{*}{$\begin{array}{l}\text { No invasive cervical cancer } \\
\text { diagnosis } 1996 \text { to 2003; alive } \\
\text { at case diagnosis; no } \\
\text { hysterectomy before } \\
\text { end point }\end{array}$} & \multirow[t]{2}{*}{ NR } & \multirow[t]{2}{*}{2000 to 2003} \\
\hline & & & & & $\begin{array}{l}\text { Excluded: smears }<3 \mathrm{~m} \\
\text { prior to case diagnosis }\end{array}$ & & & & \\
\hline \multirow[t]{2}{*}{ Zappa et al.[37] } & \multirow[t]{2}{*}{ Italy } & \multirow[t]{2}{*}{208} & \multirow[t]{2}{*}{832} & \multirow[t]{2}{*}{$<70$} & $\begin{array}{l}\text { Interval since last smear } \\
\text { (prior to index date): } \leq 3 \mathrm{y} \text {, } \\
3 \text { to } 6 y, 6+y \text {, no record }\end{array}$ & \multirow{2}{*}{$\begin{array}{l}\text { Fully invasive } \\
\text { cervical cancer; } \\
\text { excluded } \\
\text {-micro-invasive }\end{array}$} & \multirow[t]{2}{*}{$\begin{array}{l}\text { No hysterectomy prior to } \\
\text { index date; alive at } \\
\text { index date }\end{array}$} & \multirow[t]{2}{*}{ NR } & \multirow[t]{2}{*}{1994 to 1999} \\
\hline & & & & & $\begin{array}{l}\text { Excluded: smears }<12 \mathrm{~m} \\
\text { prior to diagnosis/index date }\end{array}$ & & & & \\
\hline
\end{tabular}

CIN, Cervical intraepithelial neoplasia; FIGO, International Federation of Gynecology and Obstetrics; LEEP, loop electrosurgical excision procedure; NR, not reported; $m$, months; $y$, years. 


\section{Quality assessment}

Despite concerns regarding sample selection, the one included RCT [20] was otherwise judged to have low risk of bias (Table 2). However, this research was downgraded to a moderate quality GRADE rating due to serious concerns about indirectness of the evidence for this review (Table 3). Only one of the included cohort studies [21] had exposed and unexposed groups and could therefore be assessed for risk of bias with the selected scale [39]. This study satisfied all of the criteria except one and was given a low risk rating (Table 4). Though not downgraded for any serious concerns, this evidence received an overall low quality GRADE rating (Table 3). Based on the rationale that observational research involves less rigorous methods than RCTs, these types of studies start with a low quality rating in the GRADE system [9]. Overall the 18 included case-control studies demonstrated low risk of bias (Table 4). All but two studies scored six or more out of a possible nine points on the scale with a median rating of seven. The two most common risks were use of hospital controls (eight studies) and use of self-reports and/or non-blinded interviews to ascertain exposure (nine studies). As a group, the 12 case-control studies used to answer the effectiveness of screening question was downgraded to very low GRADE quality due to concerns about indirectness of the body of evidence to the Canadian context as well as the strong likelihood of publication bias (Table 3). It should also be noted that half of these papers contained data that are at least 20 years old and all were based on screening that occurred more than 10 years ago, prior to the introduction of HPV testing.

\section{What is the effect of cervical cancer screening on} incidence of and mortality from invasive cervical cancer? A summary of the evidence available to answer the question about the effect of screening on cervical cancer mortality and incidence is presented in Table 3.

One large cluster randomized trial provided cervical cancer mortality and incidence outcomes for women with a single lifetime screen compared with women with no screening history [20]. Fifty-two villages in rural India, with a total of 131,746 healthy women ages 30 to 59 were randomly assigned to one of four groups. Women in these groups were offered a single screening by HPV test, cytology or visual inspection by acetic acid, or were told how to seek screening at local hospitals. Eight-year followup data showed the risk of dying from cervical cancer was $35 \%$ lower among women invited to screening with HPV or cytology testing than among women not offered screening (risk ratio (RR) 0.65 ; 95\% CI 0.47, $0.90 ; P=0.01$ ). Likewise, women offered screening with one of these two tests had a 44\% lower risk of being diagnosed with advanced cervical cancer (International Federation of Gynecology and Obstetrics (FIGO) stage II+) than women in the control group (relative risk ( $\mathrm{rr}$ ) 0.56; 95\% CI 0.42, 0.75; $P=0.0001$ ). However, screening by a single lifetime HPV or cytology test did not influence overall cervical cancer (FIGO stage I+) incidence (rr 1.12; 95\% CI 0.91, 1.39; $P=$ 0.28 ). The higher risk among screened women is explained by the detection of disease in the screened groups and the fact that this was the first cervical screening procedure almost all of the women had ever undergone.

Observational studies conducted in nations or regions where organized screening programs are in place and/or in countries where women are likely to participate in recurrent opportunistic screening have shown significant protective effects of cytology screening. A UK-based cohort study of 116,022 women aged 25 to 69 years demonstrated the incidence of invasive cervical cancer (FIGO stage $\mathrm{I}+$ ) was significantly lower among women who participated in the country's comprehensive screening program (that is, they had at least one cytology test in the preceding 6 to 66 months) than among women not screened during this interval ( $r r 0.38 ; 95 \%$ CI 0.23, 0.63; $P=0.0002$ ) [21]. Benefits were also apparent in a dozen case-control studies that examined exposure to cervical screening among women with invasive cervical cancer and age-matched women without the disease [15-18,23-30]. Meta-analysis of the 12 studies, which included almost 4,800 cases and 18,000 controls, showed lower odds of having undergone screening with cytology among women who were diagnosed with cervical cancer (odds ratio (OR) 0.35; 95\% CI 0.30, 0.41, $P<0.00001$ ) (Figure 2). Despite similarities in point estimates, overlapping CIs and consistency in the direction of effect across studies, the pooled result should be applied with caution given that heterogeneity statistics were significant $\left(\mathrm{Chi}^{2}=50.98\right.$, degrees of freedom $\left.(\mathrm{df})=12, P<0.00001 ; \mathrm{I}^{2}=76 \%\right)$. A number of sensitivity analyses were conducted to attempt to explain the variation. The test for subgroup differences between studies conducted in more generalizable (to the

Table 2 Risk of bias assessment of the randomized controlled trial

\begin{tabular}{|c|c|c|c|c|c|c|c|}
\hline Study & $\begin{array}{l}\text { Adequate } \\
\text { sequence } \\
\text { generation }\end{array}$ & $\begin{array}{l}\text { Concealment } \\
\text { of allocation }\end{array}$ & $\begin{array}{l}\text { Blinding of } \\
\text { participants } \\
\text { and personnel }\end{array}$ & $\begin{array}{l}\text { Blinding of } \\
\text { outcome } \\
\text { assessment }\end{array}$ & $\begin{array}{l}\text { Incomplete } \\
\text { outcome data }\end{array}$ & $\begin{array}{l}\text { Selective } \\
\text { reporting }\end{array}$ & Other bias \\
\hline $\begin{array}{l}\text { Sankaranarayanan } \\
\text { et al. [20] }\end{array}$ & $\begin{array}{l}\text { Unclear: Does } \\
\text { not specify }\end{array}$ & $\begin{array}{l}\text { High risk: } \\
\text { Probably } \\
\text { not done }\end{array}$ & $\begin{array}{l}\text { Low risk: Not } \\
\text { possible; unlikely } \\
\text { to influence results }\end{array}$ & $\begin{array}{l}\text { Low risk: } \\
\text { Probably done }\end{array}$ & $\begin{array}{l}\text { Low risk: Analysis } \\
\text { by intention } \\
\text { to screen }\end{array}$ & $\begin{array}{l}\text { Low risk: All } \\
\text { outcomes of } \\
\text { interest reported }\end{array}$ & $\begin{array}{l}\text { Low risk: No } \\
\text { other sources } \\
\text { of bias observed }\end{array}$ \\
\hline
\end{tabular}

Risk of bias was assessed using the Cochrane Risk of Bias Tool [40]. 
Table 3 Summary of findings for effect of screening on cervical cancer mortality and incidence

\begin{tabular}{|c|c|c|c|c|c|}
\hline \multirow[t]{2}{*}{ Outcome } & \multicolumn{2}{|c|}{ Illustrative comparative risks ${ }^{a}$} & \multirow[b]{2}{*}{$\begin{array}{l}\text { Relative effect } \\
(95 \% \mathrm{Cl})\end{array}$} & \multirow[b]{2}{*}{$\begin{array}{l}\text { Number of participants } \\
\text { (Number of studies) }\end{array}$} & \multirow[b]{2}{*}{$\begin{array}{l}\text { GRADE } \\
\text { quality of } \\
\text { evidence }\end{array}$} \\
\hline & $\begin{array}{l}\text { Assumed risk } \\
\text { for no screening } \\
\text { Number per million }\end{array}$ & $\begin{array}{l}\text { Corresponding risk } \\
\text { for screening } \\
\text { Number per million } \\
(95 \% \mathrm{Cl})\end{array}$ & & & \\
\hline $\begin{array}{l}\text { Cervical cancer mortality (invited to } \\
\text { HPV test or cytology versus no } \\
\text { screening) RCT; follow-up: } 8 \text { years }\end{array}$ & $2,033^{c}$ & $1,330(964,1,834)^{c}$ & $\operatorname{RR} 0.65(0.47,0.90)^{d}$ & $97,672\left(1^{\mathrm{e}}\right)$ & Moderate $e^{f, g, h, i, j}$ \\
\hline $\begin{array}{l}\text { Incidence of stage II+ cervical cancer } \\
\text { (invited to HPV test or cytology versus } \\
\text { no screening) RCT; follow-up: } 8 \text { years }\end{array}$ & $2,604^{c}$ & $1,466(1,093,1,966)^{c}$ & $\operatorname{rr} 0.56(0.42,0.75)^{d}$ & $97,672\left(1^{\mathrm{e}}\right)$ & Moderate $e^{f, g, h, i, j}$ \\
\hline $\begin{array}{l}\text { Incidence of invasive cervical cancer } \\
\text { (invited to HVP test or cytology versus } \\
\text { no screening) RCT; follow-up: } 8 \text { years }\end{array}$ & $3,747^{c}$ & $4,216(3,401,5,226)^{c}$ & rr $1.12(0.91,1.39)^{d}$ & $97,672\left(1^{\mathrm{e}}\right)$ & Moderate $e^{f, g, h, i, j}$ \\
\hline $\begin{array}{l}\text { Incidence of invasive cervical cancer } \\
\text { (cytology versus no screening) cohort } \\
\text { study; follow-up: } 3 \text { years }\end{array}$ & $1,596^{k}$ & $609(368,1,006)^{1}$ & rr $0.38(0.23,0.63)$ & $116,022\left(1^{\mathrm{m}}\right)$ & Low ${ }^{\text {g,i,j,n }}$ \\
\hline Exposure to cytology screening & 4,781 cases and 17,916 & 5 controls & OR $0.35(0.30,0.41)$ & $22,697\left(13^{\circ}\right)$ & Very low ${ }^{p, q}$ \\
\hline
\end{tabular}

(cases: diagnosed with invasive cervical

cancer; controls: no cervical cancer);

exposure: in previous 3 years to lifetime

${ }^{a}$ The assumed risk is the median control group risk. The corresponding risk (and its $95 \% \mathrm{Cl}$ ) is based on the assumed risk in the comparison group and the relative effect of the intervention (and its $95 \% \mathrm{Cl}$ ). ${ }^{\text {b }}$ High quality: Further research is very unlikely to change our confidence in the estimate of effect; Moderate quality: Further research is likely to have an important impact on our confidence in the estimate of effect and may change the estimate; Low quality: Further research is very likely to have an important impact on our confidence in the estimate of effect and is likely to change the estimate; Very low quality: We are very uncertain about the estimate. ${ }^{\mathrm{C}}$ Rates were adjusted for age by study authors. ${ }^{\mathrm{d}}$ Study authors do not provide a hazard ratio for the HPV testing and cytology groups combined versus the control group. Using sample and event data we computed a risk ratio/relative risk. ${ }^{e}$ Sankaranarayanan et al. [20]. ${ }^{f}$ Random sequence generation unclear and allocation concealment not described, however study limitations were not downgraded for these risks/uncertainties. ${ }^{9}$ Single study, therefore inconsistency not applicable. ${ }^{\mathrm{h}}$ Directness downgraded due to concerns regarding generalizability of population characteristics (rural women living in a low-income country) and intervention characteristics (one-time opportunistic screening; short duration ( 3 months) of training received by laboratory technicians responsible for processing and reading the samples) to Canadian context. ${ }^{i}$ The number of events is small $(<300$, a threshold rule of thumb value for dichotomous outcomes), however considering the specific outcome the evidence is not downgraded. ${ }^{j}$ Insufficient number of studies to assess publication bias [41]. ${ }^{k}$ Twenty cases of cervical cancer diagnosed in women who had been screened in the 0.5- to 5.5-year interval; six of these cases were screen-detected cancers while 14 cases were symptomatic cancers. ' Sixty-three cases of cervical cancer diagnosed in women who had been screened in the 0.5 - to 5.5 -year interval; 37 of these cases were screen-detected cancers while 26 cases were symptomatic cancers. ${ }^{\mathrm{m}}$ Herbert et al. [21]. ${ }^{\mathrm{n}}$ Newcastle-Ottawa Scale [39] for cohort studies was completed to assess study limitations; eight out of a possible nine stars were awarded. ${ }^{\circ}$ There are 12 included case-control studies [15-18,23-30]. The number of studies appears as 13 because two different data sets from one study [23] were used as separate entries in the meta-analysis. ${ }^{p}$ Newcastle-Ottawa Scale [39] completed to assess study quality. None of the studies satisfied all of the rating criteria. Despite some uncertainties (for example, lack of information on non-response rates in some studies) and limitations (for example, one-third of the studies used hospital controls rather than community controls), the evidence was not downgraded for study limitations. ${ }^{9}$ The Cls overlap and the directness of the effect is consistent across studies (see Figure 2); all studies favor screening and only two of the $13 \mathrm{Cls}$ marginally intersect the line of no difference. However, statistical heterogeneity is high $\left(\mathrm{Chi}^{2}=50.98, \mathrm{df}=12(P<0.00001) ; I^{2}=76 \%\right)$. Sensitivity analyses were conducted and moderate heterogeneity was found when testing for differences between studies conducted in generalizable (to Canadian context) countries versus less generalizable countries $\left(\mathrm{Chi}^{2}=2.27, \mathrm{df}=1, P=0.13, \mathrm{I}^{2}=55.95\right)$ but minimal to no heterogeneity $\left(\mathrm{I}^{2} 0 \%\right.$ to $\left.21.6 \%\right)$ was found when other differences were explored (that is, Canada and US versus other countries, screening approaches, recency of exposure, sources of screening history, diagnosis dates, sources of controls). ' Directness downgraded due to concerns regarding inclusion of both organized and opportunistic screening approaches; diversity of study locations which included developed and developing countries (Canada, US, Finland, Sweden, Japan, Italy, South Africa, Columbia, Costa Rica, Panama, Mexico); and the related potential for important differences in participants and screening procedures, particularly given that half of the studies looked at screening that occurred more than 20 years ago and all studies looked at screening that occurred more than 10 years ago. ${ }^{5}$ Publication bias was strongly suspected due to asymmetry in the funnel plot and the recognition that the risk of publication bias may be substantial for observational studies, particularly small studies that utilize data from electronic medical records or disease registries [41,42]. Cl, confidence interval; GRADE, Grading of Recommendations Assessment, Development and Evaluation; HPV, human papillomavirus; $\mathrm{OR}$, odds ratio; $\mathrm{RCT}$, randomized controlled trial; rr, relative risk; $\mathrm{RR}$, risk ratio.

Canadian context) countries versus less generalizable countries showed moderate heterogeneity $\left(\mathrm{Chi}^{2}=2.27\right.$, $\left.\mathrm{df}=1, P=0.13, \mathrm{I}^{2}=55.9 \%\right)$. All other sensitivity analyses showed minimal to no heterogeneity (Canada and US versus other countries: $\mathrm{Chi}^{2}=0.14, \mathrm{df}=1, P=0.71, \mathrm{I}^{2}=0 \%$; mass or organized screening versus spontaneous or opportunistic screening: $\mathrm{Chi}^{2}=0.56 \mathrm{df}=1, P=0.46, \mathrm{I}^{2}=$ $0 \%$; any lifetime screening exposure versus exposure in previous 3 to 6 years: $\mathrm{Chi}^{2}=0.12, \mathrm{df}=1, P=0.73, \mathrm{I}^{2}=$ $0 \%$; self-reported screening history versus verified records: $\mathrm{Chi}^{2}=1.28, \mathrm{df}=1, P=0.26, \mathrm{I}^{2}=21.6 \%$; case diagnosis date 1990s/2000s versus pre-1990s: $\mathrm{Chi}^{2}=0.14, \mathrm{df}=1$, $P=0.71, \mathrm{I}^{2}=0 \%$; community controls versus hospital controls: $\left.\mathrm{Chi}^{2}=0.35, \mathrm{df}=1, P=0.56, \mathrm{I}^{2}=0 \%\right)$.

How does varying the screening interval affect incidence of and mortality from invasive cervical cancer?

For the question regarding the optimal frequency of screening, the search located 14 studies which included 12 case-control studies that looked at exposure to cervical screening and two cohort studies that reported incidence rates for invasive cervical cancer 
Table 4 Risk of bias assessment of the observational studies ${ }^{\text {a }}$

\begin{tabular}{|c|c|c|c|c|c|c|c|c|c|c|}
\hline Cohort study & $\begin{array}{l}\text { Representativeness } \\
\text { of exposed cohort }\end{array}$ & $\begin{array}{l}\text { Selection of } \\
\text { unexposed } \\
\text { cohort }\end{array}$ & $\begin{array}{l}\text { Ascertainment } \\
\text { of exposure }\end{array}$ & $\begin{array}{l}\text { Demonstration } \\
\text { that outcome } \\
\text { not present } \\
\text { at study start }\end{array}$ & $\begin{array}{l}\text { Comparability } \\
\text { of cohorts } \\
\text { on age }\end{array}$ & $\begin{array}{l}\text { Comparability } \\
\text { of cohorts on } \\
\text { other factors }\end{array}$ & $\begin{array}{l}\text { Assessment } \\
\text { of outcome }\end{array}$ & $\begin{array}{l}\text { Adequate } \\
\text { length of } \\
\text { follow-up }\end{array}$ & $\begin{array}{l}\text { Adequacy of } \\
\text { follow-up } \\
\text { cohorts }\end{array}$ & $\begin{array}{l}\text { Overall } \\
\text { score }^{\text {b }}\end{array}$ \\
\hline $\begin{array}{l}\text { Herbert } \\
\text { et al. [21] }\end{array}$ & $\begin{array}{l}\checkmark \text { Truly } \\
\text { representative }\end{array}$ & $\begin{array}{l}\checkmark \text { Same } \\
\text { community }\end{array}$ & $\checkmark$ Secure record & $\checkmark$ Yes & $\checkmark$ Yes & No & $\begin{array}{l}\checkmark \text { Record } \\
\text { linkage }\end{array}$ & $\checkmark$ Yes (3 years) & $\begin{array}{l}\checkmark \text { All subjects } \\
\text { followed }\end{array}$ & 8 \\
\hline $\begin{array}{l}\text { Rebolj } \\
\text { et al. [22] }\end{array}$ & $x$ & & & & & & & & & \\
\hline $\begin{array}{l}\text { Case control } \\
\text { study }\end{array}$ & $\begin{array}{l}\text { Adequate case } \\
\text { definition }\end{array}$ & $\begin{array}{l}\text { Representative } \\
\text { cases }\end{array}$ & $\begin{array}{l}\text { Selection of } \\
\text { controls }\end{array}$ & $\begin{array}{l}\text { Definition of } \\
\text { controls }\end{array}$ & $\begin{array}{l}\text { Comparability } \\
\text { of controls } \\
\text { on age }\end{array}$ & $\begin{array}{l}\text { Comparability } \\
\text { of controls on } \\
\text { other factors }\end{array}$ & $\begin{array}{l}\text { Ascertainment } \\
\text { of exposure }\end{array}$ & $\begin{array}{l}\text { Method of } \\
\text { ascertainment }\end{array}$ & $\begin{array}{l}\text { Non-response } \\
\text { rate }\end{array}$ & $\begin{array}{l}\text { Overall } \\
\text { score }^{\mathbf{b}}\end{array}$ \\
\hline $\begin{array}{l}\text { Andrae } \\
\text { et al. [24] }\end{array}$ & $\begin{array}{l}\checkmark \text { Independently } \\
\text { validated }\end{array}$ & $\begin{array}{l}\checkmark \text { Consecutive } \\
\text { cases }\end{array}$ & $\begin{array}{l}\checkmark \text { Community } \\
\text { controls }\end{array}$ & $\begin{array}{l}\checkmark \text { No history } \\
\text { of disease }\end{array}$ & $\checkmark$ Yes & No & $\begin{array}{l}\checkmark \text { Secure } \\
\text { record }\end{array}$ & $\begin{array}{l}\checkmark \text { Same for } \\
\text { both groups }\end{array}$ & $\begin{array}{l}\checkmark \text { Same for } \\
\text { both groups }\end{array}$ & 8 \\
\hline $\begin{array}{l}\text { Aristizabal } \\
\text { et al. [15] }\end{array}$ & $\begin{array}{l}\checkmark \text { Independently } \\
\text { validated }\end{array}$ & $\begin{array}{l}\checkmark \text { Representative } \\
\text { cases }\end{array}$ & $\begin{array}{l}\checkmark \text { Community } \\
\text { and hospital } \\
\text { controls }\end{array}$ & Not stated & $\checkmark$ Yes & $\checkmark$ Neighborhood & $\begin{array}{l}\checkmark \text { Secure } \\
\text { record and } \\
\text { non-blinded } \\
\text { interview }\end{array}$ & $\begin{array}{l}\checkmark \text { Same for } \\
\text { both groups }\end{array}$ & Not stated & 7 \\
\hline $\begin{array}{l}\text { Berrino } \\
\text { et al. [16] }\end{array}$ & $\begin{array}{l}\checkmark \text { Independently } \\
\text { validated }\end{array}$ & $\begin{array}{l}\checkmark \text { Consecutive } \\
\text { cases }\end{array}$ & Hospital controls & $\begin{array}{l}\checkmark \text { No history } \\
\text { of disease }\end{array}$ & $\checkmark$ Yes & No & $\begin{array}{l}\text { Secure } \\
\text { record }\end{array}$ & $\begin{array}{l}\checkmark \text { Same for } \\
\text { both groups }\end{array}$ & $\begin{array}{l}\checkmark \text { Same for } \\
\text { both groups }\end{array}$ & 7 \\
\hline $\begin{array}{l}\text { Clarke and } \\
\text { Anderson [17] }\end{array}$ & $\begin{array}{l}\checkmark \text { Independently } \\
\text { validated }\end{array}$ & $\begin{array}{l}\checkmark \text { Representative } \\
\text { cases }\end{array}$ & $\begin{array}{l}\checkmark \text { Community } \\
\text { controls }\end{array}$ & Not stated & $\checkmark$ Yes & $\begin{array}{l}\checkmark \text { Neighborhood } \\
\text { and type of dwelling }\end{array}$ & $\begin{array}{l}\checkmark \text { Secure } \\
\text { record and } \\
\text { non-blinded } \\
\text { interview }\end{array}$ & $\begin{array}{l}\checkmark \text { Same for } \\
\text { both groups }\end{array}$ & $\begin{array}{l}\text { Non-respondents } \\
\text { described }\end{array}$ & 7 \\
\hline $\begin{array}{l}\text { Decker } \\
\text { et al. [25] }\end{array}$ & $\begin{array}{l}\checkmark \text { Independently } \\
\text { validated }\end{array}$ & $\begin{array}{l}\checkmark \text { Consecutive } \\
\text { cases }\end{array}$ & $\begin{array}{l}\checkmark \text { Community } \\
\text { controls }\end{array}$ & $\begin{array}{l}\checkmark \text { No history } \\
\text { of disease }\end{array}$ & $\checkmark$ & $\checkmark$ Area of residence & $\begin{array}{l}\checkmark \text { Secure } \\
\text { record }\end{array}$ & $\begin{array}{l}\checkmark \text { Same for } \\
\text { both groups }\end{array}$ & $\begin{array}{l}\checkmark \text { Same for } \\
\text { both groups }\end{array}$ & 9 \\
\hline $\begin{array}{l}\text { Hernández-Avila } \\
\text { et al. [26] }\end{array}$ & $\begin{array}{l}\checkmark \text { Independently } \\
\text { validated }\end{array}$ & $\begin{array}{l}\checkmark \text { Representative } \\
\text { cases }\end{array}$ & $\begin{array}{l}\checkmark \text { Community } \\
\text { controls }\end{array}$ & Not stated & $\checkmark$ Yes & $\begin{array}{l}\checkmark \text { Age of sexual } \\
\text { debut, \# normal } \\
\text { births, \# sex } \\
\text { partners, SES }\end{array}$ & $\begin{array}{l}\text { Non-blinded } \\
\text { interview }\end{array}$ & $\begin{array}{l}\checkmark \text { Same for } \\
\text { both groups }\end{array}$ & $\begin{array}{l}\text { Rate } \\
\text { different/no } \\
\text { designation }\end{array}$ & 6 \\
\hline $\begin{array}{l}\text { Herrero } \\
\text { et al. [18] } \\
\end{array}$ & $\begin{array}{l}\checkmark \text { Independently } \\
\text { validated }\end{array}$ & Not stated & Hospital controls & $\begin{array}{l}\checkmark \text { No history } \\
\text { of disease }\end{array}$ & No & No & $\begin{array}{l}\text { Non-blinded } \\
\text { interview }\end{array}$ & $\begin{array}{l}\checkmark \text { Same for } \\
\text { both groups }\end{array}$ & $\begin{array}{l}\checkmark \text { Same for } \\
\text { both groups }\end{array}$ & 4 \\
\hline $\begin{array}{l}\text { Hoffman } \\
\text { et al. [27] }\end{array}$ & $\begin{array}{l}\checkmark \text { Independently } \\
\text { validated }\end{array}$ & Not stated & Hospital controls & $\begin{array}{l}\checkmark \text { No history } \\
\text { of disease }\end{array}$ & $\checkmark$ Yes & $\begin{array}{l}\checkmark \text { Race, area of } \\
\text { residence, hospital }\end{array}$ & Interview & $\begin{array}{l}\checkmark \text { Same for } \\
\text { both groups }\end{array}$ & $\begin{array}{l}\checkmark \text { Same for } \\
\text { both groups }\end{array}$ & 6 \\
\hline $\begin{array}{l}\text { Jiménez-Pérez } \\
\text { and Thomas [28] }\end{array}$ & $\begin{array}{l}\checkmark \text { Independently } \\
\text { validated }\end{array}$ & $\begin{array}{l}\checkmark \text { Consecutive } \\
\text { cases }\end{array}$ & Hospital controls & $\begin{array}{l}\checkmark \text { No history } \\
\text { of disease }\end{array}$ & $\checkmark$ Yes & $\checkmark$ Area of residence & $\begin{array}{l}\text { Non-blinded } \\
\text { interview }\end{array}$ & $\begin{array}{l}\checkmark \text { Same for } \\
\text { both groups }\end{array}$ & $\begin{array}{l}\checkmark \text { Same for } \\
\text { both groups }\end{array}$ & 7 \\
\hline $\begin{array}{l}\text { Kasinpila } \\
\text { et al. [38] }\end{array}$ & $\begin{array}{l}\checkmark \text { Independently } \\
\text { validated }\end{array}$ & $\begin{array}{l}\checkmark \text { Consecutive } \\
\text { cases }\end{array}$ & Hospital controls & $\begin{array}{l}\checkmark \text { No history } \\
\text { of disease }\end{array}$ & $\checkmark$ Yes & $\begin{array}{l}\checkmark \text { Significant risk } \\
\text { factors }\end{array}$ & $\begin{array}{l}\text { Non-blinded } \\
\text { interview }\end{array}$ & $\begin{array}{l}\checkmark \text { Same for } \\
\text { both groups }\end{array}$ & $\begin{array}{l}\checkmark \text { Same for } \\
\text { both groups }\end{array}$ & 7 \\
\hline $\begin{array}{l}\text { La Vecchia } \\
\text { et al. [19] }\end{array}$ & $\begin{array}{l}\checkmark \text { Independently } \\
\text { validated }\end{array}$ & $\begin{array}{l}\checkmark \text { Representative } \\
\text { cases }\end{array}$ & Hospital controls & $\begin{array}{l}\checkmark \text { No history } \\
\text { of disease }\end{array}$ & $\checkmark$ Yes & No & Interview & $\begin{array}{l}\checkmark \text { Same for } \\
\text { both groups }\end{array}$ & $\begin{array}{l}\checkmark \text { Same for } \\
\text { both groups }\end{array}$ & 6 \\
\hline $\begin{array}{l}\text { Makino } \\
\text { et al. [29] }\end{array}$ & $\begin{array}{l}\checkmark \text { Independently } \\
\text { validated }\end{array}$ & $\begin{array}{l}\text { Potential for } \\
\text { selection bias }\end{array}$ & $\begin{array}{l}\checkmark \text { Community } \\
\text { controls }\end{array}$ & $\begin{array}{l}\checkmark \text { No history } \\
\text { of disease }\end{array}$ & $\checkmark$ Yes & $\checkmark$ Area of residence & Self-report & $\begin{array}{l}\checkmark \text { Same for } \\
\text { both groups }\end{array}$ & $\begin{array}{l}\checkmark \text { Same for } \\
\text { both groups }\end{array}$ & 7 \\
\hline $\begin{array}{l}\text { Miller } \\
\text { et al. [31] }\end{array}$ & $\begin{array}{l}\checkmark \text { Independently } \\
\text { validated }\end{array}$ & $\begin{array}{l}\text { Potential for } \\
\text { selection bias }\end{array}$ & Hospital controls & $\begin{array}{l}\checkmark \text { No history } \\
\text { of disease }\end{array}$ & $\checkmark$ Yes & $\begin{array}{l}\checkmark \text { Length of } \\
\text { membership in }\end{array}$ & $\checkmark$ Secure record & $\begin{array}{l}\checkmark \text { Same for } \\
\text { both groups }\end{array}$ & $\begin{array}{l}\checkmark \text { Same for } \\
\text { both groups }\end{array}$ & 7 \\
\hline
\end{tabular}


Table 4 Risk of bias assessment of the observational studies ${ }^{a}$ (Continued)

\begin{tabular}{|c|c|c|c|c|c|c|c|c|c|c|}
\hline & & & & & & $\begin{array}{l}\text { health program, } \\
\text { race/ethnicity }\end{array}$ & & & & \\
\hline $\begin{array}{l}\text { Nieminen } \\
\text { et al. [23] }\end{array}$ & $\begin{array}{l}\checkmark \text { Independently } \\
\text { validated }\end{array}$ & $\begin{array}{l}\checkmark \text { Consecutive } \\
\text { cases }\end{array}$ & $\begin{array}{l}\checkmark \text { Community } \\
\text { controls }\end{array}$ & Not stated & $\checkmark$ Yes & $\begin{array}{l}\checkmark \text { Socio-demographics, } \\
\text { parity, smoking }\end{array}$ & Self-report & $\begin{array}{l}\checkmark \text { Same for } \\
\text { both groups }\end{array}$ & $\begin{array}{l}\text { Rate different/ } \\
\text { no designation }\end{array}$ & 6 \\
\hline $\begin{array}{l}\text { Sasieni } \\
\text { et al. [32-35] }\end{array}$ & $\begin{array}{l}\checkmark \text { Independently } \\
\text { validated }\end{array}$ & $\begin{array}{l}\checkmark \text { Consecutive } \\
\text { cases }\end{array}$ & $\begin{array}{l}\checkmark \text { Community } \\
\text { controls }\end{array}$ & Not stated & $\checkmark$ Yes & $\checkmark$ Area of residence & $\begin{array}{l}\checkmark \text { Secure } \\
\text { record }\end{array}$ & $\begin{array}{l}\checkmark \text { Same for } \\
\text { both groups }\end{array}$ & $\begin{array}{l}\checkmark \text { Same for } \\
\text { both groups }\end{array}$ & 8 \\
\hline $\begin{array}{l}\text { Talbott } \\
\text { et al. [30] } \\
\end{array}$ & $\begin{array}{l}\checkmark \text { Independently } \\
\text { validated }\end{array}$ & $\begin{array}{l}\checkmark \text { Consecutive } \\
\text { cases }\end{array}$ & $\begin{array}{l}\checkmark \text { Community } \\
\text { controls }\end{array}$ & Not stated & $\checkmark$ Yes & $\begin{array}{l}\checkmark \text { Sex, race, street } \\
\text { or neighborhood }\end{array}$ & $\begin{array}{l}\text { Non-blinded } \\
\text { interview }\end{array}$ & $\begin{array}{l}\checkmark \text { Same for } \\
\text { both groups }\end{array}$ & $\begin{array}{l}\checkmark \text { Same for } \\
\text { both groups }\end{array}$ & 7 \\
\hline $\begin{array}{l}\text { Yang } \\
\text { et al. [36] }\end{array}$ & Record linkage & Not stated & Hospital controls & $\begin{array}{l}\checkmark \text { No history } \\
\text { of disease }\end{array}$ & $\checkmark$ Yes & No & $\begin{array}{l}\checkmark \text { Secure } \\
\text { record }\end{array}$ & $\begin{array}{l}\checkmark \text { Same for } \\
\text { both groups }\end{array}$ & $\begin{array}{l}\checkmark \text { Same for } \\
\text { both groups }\end{array}$ & 5 \\
\hline $\begin{array}{l}\text { Zappa } \\
\text { et al. [37] }\end{array}$ & $\begin{array}{l}\checkmark \text { Independently } \\
\text { validated }\end{array}$ & $\begin{array}{l}\checkmark \text { Consecutive } \\
\text { cases }\end{array}$ & $\begin{array}{l}\checkmark \text { Community } \\
\text { controls }\end{array}$ & Not stated & $\checkmark$ Yes & No & $\begin{array}{l}\checkmark \text { Secure } \\
\text { record }\end{array}$ & $\begin{array}{l}\checkmark \text { Same for } \\
\text { both groups }\end{array}$ & $\begin{array}{l}\checkmark \text { Same for } \\
\text { both groups }\end{array}$ & 7 \\
\hline
\end{tabular}

${ }^{a}$ Risk of bias was assessed using the Newcastle-Ottawa Scale [39]; ${ }^{\text {b }}$ higher overall score (maximum $=9$ ) corresponds to a lower risk of bias.

$\checkmark$ The study met this assessment criterion. $\boldsymbol{X}$ This study could not be assessed with this scale. There was no unexposed cohort; both cohorts received screening. The two groups differed in terms of their age $\checkmark$ The study 


\begin{tabular}{|c|c|c|c|c|c|c|}
\hline \multirow{2}{*}{$\begin{array}{l}\text { Study } \\
\text { Andrae et al. } 2008\end{array}$} & $\log$ [Odds Ratio] & \multirow{2}{*}{$\frac{\mathrm{SE}}{0.0726}$} & \multirow{2}{*}{$\begin{array}{r}\text { Weight } \\
11.1 \%\end{array}$} & \multirow{2}{*}{$\begin{array}{c}\text { Odds Ratio } \\
\text { IV, Random, } 95 \% \text { CI } \\
0.3968[0.3442,0.4575]\end{array}$} & \multicolumn{2}{|c|}{$\begin{array}{c}\text { Odds Ratio } \\
\text { IV, Random, } 95 \% \text { CI }\end{array}$} \\
\hline & -0.9243 & & & & - & \\
\hline Aristizabal et al. $19 \$ 4$ & -2.2966 & 0.3222 & $4.4 \%$ & $0.1006[0.0535,0.1892]$ & & \\
\hline Berrino et al. 1986 & -0.4977 & 0.2744 & $5.4 \%$ & $0.6079[0.3550,1.0409]$ & & \\
\hline Clarke et al. 1979 & -1.0032 & 0.1601 & $8.4 \%$ & $0.3667[0.2679,0.5019]$ & $\rightarrow-$ & \\
\hline Decker et al. 2009 & -1.0189 & 0.0921 & $10.6 \%$ & $0.3610[0.3014,0.4324]$ & - & \\
\hline Hemández-Avila et al. $199 \mathrm{~S}$ & -0.9676 & 0.1579 & $8.5 \%$ & $0.3800[0.2789,0.5178]$ & 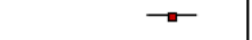 & \\
\hline Herrero et al. 1992 & -0.9163 & 0.1153 & $9.9 \%$ & $0.4000[0.3191,0.5014]$ & $\rightarrow$ & \\
\hline Hoffm an et al. 2003 & -1.204 & 0.0734 & $11.1 \%$ & $0.3000[0.2598,0.3464]$ & $\Rightarrow$ & \\
\hline Jim énez-Pérez et al. 1999 & -1.204 & 0.1768 & $7.9 \%$ & $0.3000[0.2121,0.4242]$ & ד & \\
\hline Makino et al. 1995 & -1.9661 & 0.3133 & $4.6 \%$ & $0.1400[0.0758,0.2587]$ & & \\
\hline Niem inen et al. 1999 (Organized) & -1.0217 & 0.1917 & $7.5 \%$ & $0.3600[0.2472,0.5242]$ & 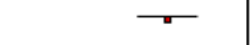 & \\
\hline Niem inen et al. 1999 (Opportunistic) & tic) -0.3147 & 0.1992 & $7.3 \%$ & $0.7300[0.4940,1.0787]$ & & \\
\hline Talbott et al. 1995 & -1.1313 & 0.3882 & $3.4 \%$ & $0.3226[0.1507,0.6904]$ & & \\
\hline Total $(95 \% \mathrm{CI})$ & & & $100.0 \%$ & $0.3490[0.2953,0.4124]$ & & \\
\hline \multicolumn{5}{|c|}{ Heterogeneity: $\mathrm{Tau}^{2}=0.06 ; \mathrm{Chi}^{2}=50.98, \mathrm{df}=12(\mathrm{P}<0.00001) ; \mathrm{I}^{2}=76 \%$} & $\begin{array}{lll} & 1 \\
0.05 & 0.2\end{array}$ & 20 \\
\hline \multicolumn{5}{|c|}{ Test for overall effect: $Z=12.36(P<0.00001)$} & $\begin{array}{l}\text { Favours Ex posure } \\
\text { to Cytology }\end{array}$ & $\begin{array}{l}\text { Favours No Exposure } \\
\text { to Cytology }\end{array}$ \\
\hline
\end{tabular}

Figure 2 Forest plot of the effect of screening on incidence of invasive cervical cancer - exposure to cytology screening.

$[16,18,19,21,22,24,27-29,31-33,35-38]$. We found no studies that reported cervical mortality outcomes related to screening intervals. Methodological variations (for example, in interval durations, interval groupings, diagnostic test exclusion periods) prevented pooling data from these studies; thus this review is unable to provide definitive answers on how often to screen. However, the evidence does offer some indications that are useful for decision-making. First, the shortest screening interval considered within each study consistently offered the greatest protective effects (for example, $<1$ year OR 0.14 (no CI given) [16]; $<1$ year OR $0.18(95 \%$ CI $0.09,0.35)$ [32]; 1 year OR 0.09 (95\% CI 0.06, 0.16) [29]; <3 years OR $0.12(95 \%$ CI $0.07,0.20)$ [19]; <3 years OR 0.25 (95\% CI $0.15,0.42$ ) [37]). Second, screening intervals of five years or less appeared to offer women substantial protection against invasive cervical cancer (for example, $<5$ years OR 0.3 (95\% CI $0.2,0.4)$ [27]; 1 to 5 years OR 0.2 (95\% CI 0.1 , $0.5)$ [28]; 1 to 3 years OR 0.27 (95\% CI $0.13,0.56)$ [38]; 2 years OR 0.17 (95\% CI 0.08, 0.34) [29]). Third, the protective effect of screening diminished with longer intervals between tests but even intervals of 10 to 15 years showed significant protective benefits (for example, 10 to 14 year interval OR 0.4 (95\% CI 0.3 , $0.5)$; $\geq 15$ year interval OR 0.5 (95\% CI 0.4, 0.7) [27]). Finally, regardless of the specific interval, any lifetime screening was better than no history of screening (for example, interval $>5.5$ years compared to never screened RR 0.34 (95\% CI 0.14, 0.82) [21]; interval $\geq 6$ years compared to never screened OR 0.56 (95\% CI $0.38,0.82)[37])$.
How does varying the age at which screening is started or stopped reduce incidence of and mortality from invasive cervical cancer?

For the question on optimal ages to start and stop screening, the search located four studies including three casecontrol studies that examined exposure to screening among different age groups and one age comparison within a cohort study that reported incidence rates for invasive cervical cancer [22,24,27,32-34]. No studies were found that looked specifically at the age to stop screening; only one study investigated the protective benefit of screening among older women [24]. We found no studies that reported cervical cancer mortality outcomes related to age and screening history. Methodological variations across studies (for example, in overall age ranges, age groupings used for analysis) prevented pooling the data. Given the available evidence we were not able to definitively answer the question regarding ages to initiate and discontinue cervical screening, however we were able to draw a few themes from the data. Participation trends showed very high screening attendance among young women, high attendance among middle-aged women, and consistently lower participation in older groups of women $[32,33]$. Despite very high participation among younger women, the benefit of screening below age 30 is unclear. Significant benefits were found in one study (OR 0.42; 95\% CI 0.24, 0.74) [24], non-significant benefits were observed in another study (OR 0.7; 95\% CI 0.3, 2.1) [27], and no benefits were found in a third study (screened at ages 20 to 21 OR 1.51; 95\% CI 0.95, 2.38; screened at ages 22 to 24. OR 1.11; 95\% CI 0.83, 1.50) [34]. Screening decisions for women under age 30 must consider the balance 
between potential benefits and potential harms and economic costs. Alternatively, the evidence indicates exposure to cytology screening provides a substantial protective effect in women 30 years and older (for example, screened at ages 30 to 65 OR 0.40 (95\% CI 0.34, 0.47) [24]; ages 40 to 59 OR $0.3(95 \%$ CI $0.2,0.4)$ [27]; ages 42 to 44 OR 0.37 (95\% CI $0.29,0.48$ ); ages 52 to 54 OR 0.26 (95\% CI 0.19 , 0.36 ) [34]) and there is some evidence this protective effect remains strong in women over 65 years (OR 0.36; 95\% CI $0.24,0.53)[24]$.

\section{Discussion and conclusions}

The ultimate goal of cervical screening is to decrease the incidence of and subsequent mortality from invasive cervical cancer. The available evidence supports the conclusion that screening does offer protective benefits and is associated with a reduction in these critical outcomes. An RCT in India showed that even a single lifetime screening test significantly decreased mortality from and incidence of advanced cervical cancer compared to no screening. Cytology screening was shown to be beneficial in a cohort study that found testing significantly reduced the incidence of invasive cervical cancer compared to no screening. Pooled evidence from a dozen case-control studies also indicated a significant protective effect of cytology screening. This review found no conclusive evidence for establishing optimal ages to start and stop cervical screening, or to determine how often to screen; however the available data suggests substantial protective effects for screening women 30 years and older and for intervals of up to five years.

\section{Limitations}

The findings are impacted by the biases and limitations of the literature and the included studies. For the question on the effect of cervical screening on the outcome of mortality, all of the data came from one RCT of a single lifetime screen offered to women in rural villages in India with follow-up limited to eight years. The bulk of the evidence used to assess the effect of screening on the incidence of invasive cervical cancer and to address the questions about optimal screening intervals and ages was taken from low and very low GRADE quality observational studies, the results of which need to be considered with caution. Further, aside from the location of the studies offering some explanation, the large amount of heterogeneity between studies included in the metaanalysis cannot be accounted for by the factors explored in the sensitivity analyses; consequently the pooled estimate should also be applied with caution. It is also important to acknowledge the potential for observational studies to present additional risks that could introduce bias in favor of screening including: earlier diagnosis in screen-detected cases (lead bias), over-representation of women with a lengthy pre-clinical stage (length bias), and over-representation of healthier participants among those who attend for screening (volunteer bias). Finally, we restricted our search to papers in English or French, thus we may have missed relevant data in papers written in other languages.

\section{Implications for further research}

Although this review identified research evidence that supports the practice of cervical cancer screening, there remain unanswered questions, particularly about newer HPV technologies. Compared to studies that focus on outcomes after cytology screening, the evidence base concerning the relative effectiveness of HPV screening is limited. While minimal evidence was found for cytological testing, no studies were found that looked at optimal screening intervals or ages to commence or discontinue HPV testing that also met the inclusion criteria (for example, included outcomes of invasive cancer incidence and mortality). More evidence is needed on the harms of HPV testing (for example. false positive rates) and the related potential for unnecessary, and possibly harmful, diagnostic and treatment procedures. The HPV FOCAL Trial, currently underway in British Columbia, is one study that may provide answers to some of these important questions [43].

\section{Abbreviations}

df: Degrees of freedom; FIGO: International Federation of Gynecology and Obstetrics; GRADE: Grading of Recommendations Assessment, Development and Evaluation; HPV: Human papillomavirus; OR: Odds ratio; RCT: Randomized controlled trial; rr: Relative risk; RR: Risk ratio; USPSTF: United States Preventive Services Task Force.

\section{Competing interests}

The authors declare that they have no competing interests.

\section{Authors' contributions}

All authors performed tasks involved in conducting the full systematic review. LP drafted the initial version of the manuscript. All authors reviewed, contributed revisions and approved the final manuscript prior to submission.

\section{Acknowledgements}

Other MERSC contributors included Pat Carson, Mahbubul Haq, Sharon PeckReid and Maureen Rice. Methodological consultation was provided by Sohel Nazmul, Mark Oremus, Nancy Santesso and Harry Shannon. Clinical expertise was provided by Laurie Elit. Canadian Task Force on Preventive Health Care members who contributed to protocol development and/or discussion of findings included the Cervical Cancer Screening Guideline Working Group: Richard Birtwhistle, James Dickinson, Michel Joffres, Gabriela Lewin, Elizabeth Shaw, Harminder Singh and Marcello Tonelli. External Working Group members included Verna Mai and C. Meg McLachlin. Public Health Agency of Canada officers involved with the review and the guideline included Sarah Connor Gorber, Lesley Dunfield, Sue Pollock and Eva Tsakonas.

Funding for this review is from the Canadian Institutes of Health Research. The views expressed herein are the opinions of the authors and do not necessarily represent the views of the Canadian Institutes of Health Research.

Note

This paper is based on a full report conducted by the McMaster Evidence Review and Synthesis Centre entitled Screening for Cervical Cancer which can be found at http://canadiantaskforce.ca/wp-content/uploads/2013/01/ Systematic-Review-Cervical-Cancer.pdf?9d7bd4. 
Received: 5 November 2012 Accepted: 8 May 2013

Published: 24 May 2013

\section{References}

1. Pontén J, Adami HO, Bergström R, Dillner J, Friberg LG, Gustafsson L, Miller $A B$, Parkin DM, Sparén P, Trichopoulos D: Strategies for global control of cervical cancer. Int J Cancer 1995, 60:1-26.

2. Peirson L, Fitzpatrick-Lewis D, Ciliska D, Warren R: Screening for Cervical Cancer. Hamilton, ON: McMaster Evidence Review and Synthesis Centre; 2012.

3. Canadian Task Force on Preventive Health Care: Recommendations on screening for cervical cancer. CMAJ 2013, 185:35-45.

4. McCredie MR, Sharples KJ, Paul C, Baranyai J, Medley G, Jones RW, Skegg DC: Natural history of cervical neoplasia and risk of invasive cancer in women with cervical intraepithelial neoplasia 3: a retrospective cohort study. Lancet Oncol 2008, 9:425-434.

5. Sasieni P, Adams J: Effect of screening on cervical cancer mortality in England and Wales: analysis of trends with an age period cohort model. BMJ 1999, 318:1244-1245.

6. van der Aa MA, Pukkala E, Coebergh JWW, Anttila A, Siesling S: Mass screening programmes and trends in cervical cancer in Finland and the Netherlands. Int I Cancer 2008, 122:1854-1858.

7. United States Preventive Services Task Force: Screening for Cervical Cancer. Alexandria, VA: USPSTF; 1996.

8. Vesco KK, Witlock EP, Eder M, Lin J, Burda BU, Senger CA, Holmes RS, Fu R, Zuber S: Screening for Cervical Cancer: a Systematic Evidence Review for the U.S. Preventive Services Task Force. Rockville, MD: Agency for Healthcare Research and Quality (US); 2011.

9. Guyatt GH, Oxman AD, Vist GE, Kunz R, Falck-Ytter Y, Alonso-Coello P, Schunemann HJ: GRADE: an emerging consensus on rating quality of evidence and strength of recommendations. BMJ 2008, 336:924-926.

10. Review Manager (RevMan): Version 5.1. Copenhagen: The Nordic Cochrane Centre, The Cochrane Collaboration; 2011.

11. DerSimonian R, Laird N: Meta-analysis in clinical trials. Control Clin Trials 1986, 7:177-188.

12. Fleiss JL: The statistical basis of meta-analysis. Stat Methods Med Res 1993, 2:121-145.

13. Higgins JP, Thompson SG: Quantifying heterogeneity in a meta-analysis. Stat Med 2002, 21:1539-1558.

14. Deeks JJ, Higgins JP, Altman DG, the Cochrane Methods Group: Analysing data and undertaking meta-analyses. In Cochrane Handbook for Systematic Reviews of Interventions 5.0.2 (Updated September 2009). 502nd edition. Chichester, UK: Wiley; 2009.

15. Aristizabal N, Cuello C, Correa P, Collazos T, Haenszel W: The impact of vaginal cytology on cervical cancer risks in Cali, Colombia. Int J Cancer 1984, 34:5-9.

16. Berrino F, Gatta G, D'Alto M, Crosignani P, Riboli E: Efficacy of screening in preventing invasive cervical cancer: a case-control study in Milan, Italy. IARC Sci Publ 1986, 76:111-123.

17. Clarke EA, Anderson TW: Does screening by "Pap" smears help prevent cervical cancer? A case-control study. Lancet 1979, 2:1-4.

18. Herrero R, Brinton LA, Reeves WC, Brenes MM, de Britton RC, Gaitan E, Tenorio F: Screening for cervical cancer in Latin America: a case-control study. Int J Epidemiol 1992, 21:1050-1056.

19. La Vecchia C, Franceschi S, Decarli A, Fasoli M, Gentile A, Tognoni G: "Pap" smear and the risk of cervical neoplasia: quantitative estimates from a case-control study. Lancet 1984, 2:779-782.

20. Sankaranarayanan R, Nene BM, Shastri SS, Jayant K, Muwonge R, Budukh AM, Hingmire S, Malvi SG, Thorat R, Kothari A, Chinoy R, Kelkar R, Kane S, Desai S, Keskar VR, Rajeshwarkar R, Panse N, Dinshaw KA: HPV screening for cervical cancer in rural India. N Engl J Med 2009, 360:1385-1394.

21. Herbert A, Stein K, Bryant TN, Breen C, Old P: Relation between the incidence of invasive cervical cancer and the screening interval: is a five year interval too long? J Med Screen 1996, 3:140-145.

22. Rebolj M, van Ballegooijen M, Lynge E, Looman C, Essink-Bot ML, Boer R, Habbema D: Incidence of cervical cancer after several negative smear results by age 50: prospective observational study. BMJ 2009, 338:b1354

23. Nieminen P, Kallio M, Anttila A, Hakama M: Organised vs. spontaneous Pap-smear screening for cervical cancer: a case-control study. Int J Cancer 1999, 83:55-58.
24. Andrae B, Kemetli L, Sparén P, Silfverdal L, Strander B, Ryd W, Dillner J, Törnberg S: Screening-preventable cervical cancer risks: evidence from a nationwide audit in Sweden. J Nat/ Cancer Inst 2008, 100:622-629.

25. Decker K, Demers A, Chateau D, Musto G, Nugent Z, Lotocki R, Harrison M: Papanicolaou test utilization and frequency of screening opportunities among women diagnosed with cervical cancer. Open Med 2009, 3:e140-e147.

26. Hernández-Avila M, Lazcano-Ponce EC, de Ruíz PA, Romieu I: Evaluation of the cervical cancer screening programme in Mexico: a population-based case-control study. Int J Epidemiol 1998, 27:370-376.

27. Hoffman M, Cooper D, Carrara H, Rosenberg L, Kelly J, Stander I, Williamson AL, Denny L, du Toit G, Shapiro S: Limited Pap screening associated with reduced risk of cervical cancer in South Africa. Int J Epidemiol 2003, 32:573-577.

28. Jiménez-Pérez M, Thomas DB: Has the use of pap smears reduced the risk of invasive cervical cancer in Guadalajara, Mexico? Int I Cancer 1999, 82:804-809.

29. Makino H, Sato S, Yajima A, Komatsu S, Fukao A: Evaluation of the effectiveness of cervical cancer screening: a case-control study in Miyagi, Japan. Tohoku J Exp Med 1995, 175:171-178.

30. Talbott EO, Norman SA, Kuller LH, Ishii EK, Baffone KM, Dunn MS, Krampe $B R$, Weinberg GB: Refining preventive strategies for invasive cervical cancer: a population-based case-control study. J Womens Health (Larchmt) 1995, 4:387-395.

31. Miller MG, Sung HY, Sawaya GF, Kearney KA, Kinney W, Hiatt RA: Screening interval and risk of invasive squamous cell cervical cancer. Obstet Gynecol 2003, 101:29-37.

32. Sasieni PD, Cuzick J, Lynch-Farmery E: Estimating the efficacy of screening by auditing smear histories of women with and without cervical cancer. The National Co-ordinating Network for Cervical Screening Working Group. Br J Cancer 1996, 73:1001-1005.

33. Sasieni $P$, Adams J, Cuzick J: Benefit of cervical screening at different ages: evidence from the UK audit of screening histories. Br J Cancer 2003, 89:88-93.

34. Sasieni P, Castanon A, Cuzick J: Effectiveness of cervical screening with age: population based case-control study of prospectively recorded data. BMJ 2009, 339:b2968.

35. Sasieni P, Castanon A, Cuzick J: Screening and adenocarcinoma of the cervix. Int J Cancer 2009, 125:525-529.

36. Yang B, Morrell S, Zuo Y, Roder D, Tracey E, Jelfs P: A case-control study of the protective benefit of cervical screening against invasive cervical cancer in NSW women. Cancer Cause Control 2008, 19:569-576.

37. Zappa M, Visioli CB, Ciatto S, lossa A, Paci E, Sasieni P: Lower protection of cytological screening for adenocarcinomas and shorter protection for younger women: the results of a case-control study in Florence. $\mathrm{Br} J$ Cancer 2004, 90:1784-1786.

38. Kasinpila C, Promthet S, Vatanasapt P, Sasieni P, Parkin DM: Evaluation of the nationwide cervical screening programme in Thailand: a casecontrol study. J Med Screen 2011, 18:147-153.

39. Wells GA, Shea BJ, O'Connell D, Peterson J, Welch W, Losos M, Tugwell P: The Newcastle-Ottawa Scale (NOS) for assessing the quality of nonrandomised studies in meta-analyses. 2000 [http://www.ohri.ca/ programs/clinical_epidemiology/oxford.asp]

40. Higgins JPT, Altman DG: Assessing risk of bias in included studies. In Cochrane Handbook for Systematic Reviews of Interventions. Edited by Higgins JPT, Green S. West Sussex, UK: Wiley; 2008:187-241.

41. Sterne JAC, Egger M, Moher D: Addressing reporting biases. In Cochrane Handbook for Systematic Reviews of Interventions. Edited by Higgins JPT, Green S. West Sussex,UK: Wiley; 2008:297-333.

42. Guyatt GH, Oxman AD, Montori V, Vist G, Kunz R, Brozek J, Alonso-Coello P, Djulbegovic B, Atkins D, Falck-Ytter Y, Williams JW Jr, Meerpohl J, Norris SL, AkI EA, Schünemann H: GRADE guidelines: 5 . Rating the quality of evidence-publication bias. J Clin Epidemiol 2011, 64:1277-1282.

43. Ogilvie GS, van Niekerk DJ, Krajden M, Martin RE, Ehlen TG, Ceballos K, Peacock SJ, Smith LW, Kan L, Cook DA, Mei W, Stuart GC, Franco EL, Coldman AJ: A randomized controlled trial of Human Papillomavirus (HPV) testing for cervical cancer screening: trial design and preliminary results (HPV FOCAL Trial). BMC Cancer 2010, 10:111.

doi:10.1186/2046-4053-2-35

Cite this article as: Peirson et al:: Screening for cervical cancer: a systematic review and meta-analysis. Systematic Reviews 2013 2:35. 